\title{
Aerobic oxidative coupling of alcohols and amines to imines over iron catalysts supported on mesoporous carbon
}

\author{
Longlong Geng, Jinling Song, Bin Zheng, Shujie Wu, Wenxiang Zhang, Mingjun Jia, Gang Liu* \\ Key Laboratory of Surface and Interface Chemistry of Jilin Province, College of Chemistry, Jilin University, Changchun 130012, Jilin, China
}

\section{A R T I C L E I N F O}

\section{Article history:}

Received 30 May 2016

Accepted 12 July 2016

Published 5 September 2016

\section{Keywords:}

Iron catalyst

Imine synthesis

Oxidative coupling

Mesoporous carbon

Molecular oxygen

\begin{abstract}
A B S T R A C T
Direct oxidative coupling of an alcohol and amine, with air or molecular oxygen as the oxygen source, is an environmentally friendly method for imine synthesis. We developed an Fe catalyst supported on mesoporous carbon (denoted by $\mathrm{FeO}_{x} / \mathrm{HCMK}-3$ ) for this reaction with excellent activity and recyclability. $\mathrm{FeO}_{x} / \mathrm{HCMK}-3$ was prepared by impregnating $\mathrm{HNO}_{3}$-treated mesoporous carbon (CMK-3) with iron nitrate solution. The highly dispersed $\mathrm{FeO}_{x}$ species give $\mathrm{FeO}_{x} / \mathrm{HCMK}-3$ high reducibility and are responsible for the high catalytic performance. Imine synthesis over $\mathrm{FeO}_{x} / \mathrm{HCMK}-3$ follows a redox mechanism. The oxygen species in $\mathrm{FeO}_{x} / \mathrm{HCMK}-3$ participate in the reaction and are then regenerated by oxidation with molecular $\mathrm{O}_{2}$. The reaction involves two consecutive steps: oxidative dehydrogenation of an alcohol to an aldehyde and coupling of the aldehyde with an amine to give an imine. Oxidative dehydrogenation of the alcohol is the rate-determining step in the reaction.
\end{abstract}

(C) 2016, Dalian Institute of Chemical Physics, Chinese Academy of Sciences. Published by Elsevier B.V. All rights reserved.

\section{Introduction}

Imines are important nitrogen compounds; they contain a reactive $\mathrm{C}=\mathrm{N}$ moiety $[1,2]$. Imines are nitrogen sources and can undergo various transformations. They are widely used in biological, agricultural, and pharmaceutical synthetic processes [3-6]. The condensation of aldehydes or ketones with amines is the traditional method for imine synthesis, and is usually performed in the presence of an acidic catalyst [7-9]. Recently, the direct oxidative coupling of an alcohol and amine to give an imine has attracted increasing attention because of its environmentally friendly properties [10-16]. Air or molecular oxygen can be used as the oxygen source for the production of various types of desirable imines from appropriate alcohols and amines as starting reagents, with water as the only by-product. Effective noble-metal-based homogeneous and heterogeneous catalysts such as supported $\mathrm{Au}, \mathrm{Ru}, \mathrm{Pd}$, and $\mathrm{Pt}$ have been reported [17-24]. However, the high price of these noble metals and the need to use inorganic or organic bases as additives in the reaction system limit their large-scale application in imine synthesis.

Recently, a few metal oxide catalysts that can catalyze this imine synthesis have been reported [25-27]; for example, $\mathrm{CeO}_{2}$ is an effective catalyst for imine formation from benzyl alcohol and aniline at low temperature $\left(60{ }^{\circ} \mathrm{C}\right)$, with a high yield of $96 \%$ after $24 \mathrm{~h}$ [25]. Manganese oxides supported on hydroxyapatite $\left(\mathrm{MnO}_{x} / \mathrm{HAP}\right)$ also show high activity in the oxidative coupling of alcohols and amines [26]. When benzyl alcohol and aniline were used, a $92 \%$ yield of the imine was obtained after reaction for $24 \mathrm{~h}$ at $80^{\circ} \mathrm{C}$. The catalytic activity, especially the capacity to activate molecular oxygen, is highly dependent on the redox properties of the metal oxides. They determine the

\footnotetext{
* Corresponding author. Tel: +86-431-85155390; Fax: +86-431-88499140; E-mail: lgang@jlu.edu.cn

This work was supported by the National Natural Science Foundation of China $(21473073,21473074)$ and the "13th Five-Year" Science and Technology Research of the Education Department of Jilin Province (2016403).

DOI: 10.1016/S1872-2067(16)62506-8 | http://www.sciencedirect.com/science/journal/18722067 | Chin. J. Catal., Vol. 37, No. 9, September 2016
} 
catalytic behavior of the metal oxide in the oxidative dehydrogenation step. Tuning the redox properties of metal oxide catalysts should therefore be an efficient method for developing high-performance catalysts for imine synthesis via oxidative coupling.

Among various metal oxides, iron oxides have the advantages of ready availability, low cost, and low toxicity [28-32]. However, iron oxides show low activities in the oxidative coupling of alcohols and amines to imines [25]. This could be related to the intrinsic inert properties of a bulk material, such as a low surface-to-bulk atomic ratio and low surface energy. We recently reported that the redox properties of iron oxides can be tuned by forming highly dispersed iron oxide species on carbon supports $[33,34]$. The catalysts show high redox activities in $\mathrm{O}_{2}$ activation. This property of these iron oxide species might enable them to catalyze oxidative coupling of alcohols and amines to imines.

In this work, carbon-supported $\mathrm{FeO}_{x}\left(\mathrm{FeO}_{x} / \mathrm{HCMK}-3\right)$ was used as a catalyst for oxidative coupling of alcohols and amines to imines. A 98.8\% yield of imine was obtained in the oxidative coupling of benzyl alcohol and aniline after reaction for $6 \mathrm{~h}$ at $80{ }^{\circ} \mathrm{C}$. The $\mathrm{FeO}_{x} / \mathrm{HCMK}-3$ catalyst was efficient in the synthesis of a series of imine compounds. The correlations between the activity and physicochemical properties of the catalyst were investigated based on a series of characterization results. The reaction mechanism of imine synthesis over $\mathrm{FeO}_{x} / \mathrm{HCMK}-3$ was also explored.

\section{Experimental}

\subsection{Materials}

All chemicals were analytical grade and used without further purification. Double-distilled water was used in all experiments.

\subsection{Catalyst preparation}

SBA-15 templates were prepared using a triblock copolymer, $\mathrm{EO}_{20}-\mathrm{PO}_{70}-\mathrm{EO}_{20}$ (P123; EO: ethylene oxide; PO: propylene oxide), as the surfactant and tetraethyl orthosilicate (TEOS) as the silica source, using the procedure reported by Zhao et al. [35]. Typically, TEOS (4.68 $\mathrm{mL}$ ) was added to $2 \mathrm{~mol} / \mathrm{L} \mathrm{HCl} \mathrm{(60}$ $\mathrm{mL})$ containing P123 (2 g) at $35{ }^{\circ} \mathrm{C}$. After stirring in a water bath $\left(35^{\circ} \mathrm{C}\right)$ for $24 \mathrm{~h}$, the mixture was transferred to Teflon-lined stainless steel autoclaves $(100 \mathrm{~mL})$ and heated to 100 ${ }^{\circ} \mathrm{C}$ for $3 \mathrm{~d}$. The resultant solid product was separated by filtration, dried at $100^{\circ} \mathrm{C}$ for $12 \mathrm{~h}$, and calcined at $550{ }^{\circ} \mathrm{C}$ for $6 \mathrm{~h}$.

CMK-3 was prepared using SBA-15 as a hard template and sucrose as the carbon source [36]. Typically, SBA-15 silica (1.0 g) was added to a solution containing sucrose (1.25 g), sulfuric acid (0.14 g), and distilled water (5.0 g). The mixture was kept in an oven for $6 \mathrm{~h}$ at $80^{\circ} \mathrm{C}$. The temperature was then increased to $160{ }^{\circ} \mathrm{C}$ and maintained for $6 \mathrm{~h}$. The heating procedure was repeated after addition of the carbon precursor $(0.8 \mathrm{~g}$ of sucrose, $0.09 \mathrm{~g}$ of $\mathrm{H}_{2} \mathrm{SO}_{4}$, and $5.0 \mathrm{~g}$ of $\mathrm{H}_{2} \mathrm{O}$ ) to achieve complete infiltration of the internal pores of the SBA-15 silica. The car- bon-silica composite was obtained by pyrolysis at $900{ }^{\circ} \mathrm{C}$ for 6 $\mathrm{h}$ under an Ar flow and then washing in $10 \mathrm{wt} \% \mathrm{HF}$ aqueous solution to remove the silica template.

The carbon-supported iron oxide catalyst was prepared using a wet impregnation method. Typically, an Fe-containing solution was obtained by dissolving $\mathrm{Fe}\left(\mathrm{NO}_{3}\right)_{3} \cdot 9 \mathrm{H}_{2} \mathrm{O}$ in a certain amount of water. Before added to the iron nitrate solution, the CMK-3 support was treated in $4 \mathrm{~mol} / \mathrm{L} \mathrm{HNO}_{3}$ solution at $60{ }^{\circ} \mathrm{C}$ for $6 \mathrm{~h}$ (denoted by HCMK-3). After stirring for about $3 \mathrm{~h}$ at room temperature, the mixture was heated at $80{ }^{\circ} \mathrm{C}$ under atmospheric pressure to evaporate the water. The as-synthesized catalyst was thermally treated at $400{ }^{\circ} \mathrm{C}$ for $4 \mathrm{~h}$ under an $\mathrm{Ar}$ flow. The iron oxide loading was $5 \mathrm{wt} \%$ (calculated based on $\mathrm{Fe}_{2} \mathrm{O}_{3}$ ) and the resultant material was denoted by $\mathrm{FeO}_{x} / \mathrm{HCMK}-3$. For comparison, a sample consisting of $\mathrm{Fe}^{3+}$ ions supported on HCMK-3 (denoted by Fe-HCMK-3) was also prepared by the same impregnation method and using $\mathrm{HNO}_{3}$-treated CMK-3 as a support. The difference was that after impregnation the sample was dried in an oven at $80^{\circ} \mathrm{C}$ for $12 \mathrm{~h}$ without further thermal treatment at $400{ }^{\circ} \mathrm{C}$ in an Ar flow for 4 h. The $\mathrm{Fe}$ species loading was the same as that on $\mathrm{FeO}_{x}$ /HCMK-3. Bulk $\mathrm{Fe}_{2} \mathrm{O}_{3}$ was also prepared using a conventional precipitation method with $\mathrm{Fe}(\mathrm{NO})_{3} \cdot 9 \mathrm{H}_{2} \mathrm{O}$ as the $\mathrm{Fe}$ source and ammonia as the precipitating agent $(\mathrm{pH} 9)$. The resultant material was calcined at $400^{\circ} \mathrm{C}$ for $4 \mathrm{~h}$ in air.

\subsection{Catalyst characterization}

Powder X-ray diffraction (XRD) patterns were recorded with a Rigaku X-ray diffractometer using $\mathrm{Cu} K_{\alpha}$ radiation $(\lambda=$ $1.5418 \AA$ Å). Transmission electron microscopy (TEM) images and high-angle annular dark field scanning TEM (HAADF-STEM) images were obtained using a FEI Tecnai F20 instrument with an accelerating voltage of $200 \mathrm{kV}$, equipped with an energy-dispersive X-ray spectroscopy analyzer. X-ray photoelectron spectroscopy (XPS) was performed using a Thermo ESCA LAB 250 system with an Mg $K_{\alpha}$ source (1254.6 eV). $\mathrm{N}_{2}$ adsorption-desorption isotherms were recorded at $-196{ }^{\circ} \mathrm{C}$ using a Micromeritics ASAP 2010N analyzer. Raman spectra were recorded using a Bruker RFS 100 Raman spectrometer with an Ar laser (532 nm) as the excitation source. Temperature-programmed reduction (TPR) was performed using a Tianjin Xianquan TP-5079 adsorption analyzer. Before examination, the catalysts $\left(30 \mathrm{mg}\right.$ of $\mathrm{FeO}_{x} / \mathrm{HCMK}-3,10 \mathrm{mg}$ of $\mathrm{Fe}_{2} \mathrm{O}_{3}$ ) were treated in an $\mathrm{Ar}(99.99 \%)$ flow at $400{ }^{\circ} \mathrm{C}$ for 30 min. The zeta-potential curve was plotted as a function of $\mathrm{pH}$, from 2 to 8 (Zeta PALS analyzer, Brookhaven Instruments Corporation, USA). The sample was suspended in aqueous 0.01 $\mathrm{mol} / \mathrm{L} \mathrm{NaCl}$ solution. The $\mathrm{pH}$ was adjusted using $1.0 \mathrm{~mol} / \mathrm{L}$ $\mathrm{NaOH}$ and $\mathrm{HCl}$ solutions. The Fe content was estimated using inductively coupled plasma atomic emission spectroscopy (ICP-AES; Perkin-Elmer emission spectrometer). Fourier transform infrared (FT-IR) spectra were recorded using a Thermo Nicolet 6700 FT-IR spectrometer. The Boehm titration method was used to determine the amounts of surface groups. The carbon support (100 mg) was placed in $10 \mathrm{~mL}$ of a 0.05 mol/L solution containing $\mathrm{NaOH}, \mathrm{Na}_{2} \mathrm{CO}_{3}$, and $\mathrm{NaHCO}_{3}$. The 
vials were sealed and shaken for $24 \mathrm{~h}$, and the contents were filtered. A known quantity of $\mathrm{HCl}$ was added to each filtrate. The excess acid left in the solution was titrated with $\mathrm{NaOH}$ using an automatic potentiometer titrator (LeiCi ZDT-4A). The amounts of acidic sites were calculated based on the assumption that $\mathrm{NaOH}$ neutralizes carboxylic, phenolic, and lactonic groups, $\mathrm{NaHCO}_{3}$ neutralizes carboxylic groups, and $\mathrm{Na}_{2} \mathrm{CO}_{3}$ neutralizes carboxylic and lactonic groups.

\subsection{Catalytic tests}

The aerobic oxidative coupling of an alcohol and amine was performed in a 50-mL two-necked flask at atmospheric pressure. A quantity of catalyst $(0.3 \mathrm{~g})$ was added to the reactor containing alcohol $(1.0 \mathrm{mmol})$, amine $(2.0 \mathrm{mmol})$, and toluene $(10 \mathrm{~mL})$. The mixture was in contact with air, and the reaction temperature was kept at $80{ }^{\circ} \mathrm{C}$. The reaction mixture was extracted via a sampling pipe with a filtrator and then transferred to a vial. The products were analyzed using a gas chromatograph equipped with an HP-5 column and a flame ionization detector. The conversion and yield of the imine product were calculated based on the alcohol to imine ratio. The products were identified using standard compounds and gas chromatography-mass spectrometry. The turnover frequencies (TOFs) were calculated based on benzyl alcohol conversion in the initial stage $\left(60 \mathrm{~min}\right.$ ) and the amount of $\mathrm{FeO}_{x}$ in the catalyst.

An oxygen-free experiment was performed in a Schlenk tube. First, the $\mathrm{FeO}_{x} / \mathrm{HCMK}-3$ catalyst was put in a Schlenk tube, and degassed at $80{ }^{\circ} \mathrm{C}$ for $1.5 \mathrm{~h}$ under vacuum to remove adsorbed $\mathrm{O}_{2}$. High-purity $\mathrm{N}_{2}$ (99.99\%) was injected into the Schlenk tube until the pressure was $1 \mathrm{~atm}$. The degassed toluene, benzyl alcohol, and aniline were added to the Schlenk tube. The system was further degassed and balanced with high purity $\mathrm{N}_{2}$. The Schlenk tube was then put in an oil bath $\left(80^{\circ} \mathrm{C}\right)$ to start the reaction. After each sample extraction, the system was degassed and balanced with high purity $\mathrm{N}_{2}$. All these treatments were to ensure the removal of molecular $\mathrm{O}_{2}$ from the system. In the recycling experiments, the solid catalyst was separated by filtration and treated at $400{ }^{\circ} \mathrm{C}$ for $1 \mathrm{~h}$ before the next cycle.

\section{Results and discussion}

\subsection{Catalyst structure and surface properties}

Fig. 1 shows the preparation of the carbon-supported $\mathrm{FeO}_{x}$ ( $5 \mathrm{wt} \%$, calculated based on $\mathrm{Fe}_{2} \mathrm{O}_{3}$ ) catalyst. The catalyst support was ordered mesoporous carbon CMK-3 prepared via a hard-template method. The CMK-3 was treated with $4 \mathrm{~mol} / \mathrm{L}$ $\mathrm{HNO}_{3}$ at $60{ }^{\circ} \mathrm{C}$ for $6 \mathrm{~h}$ before use as the catalyst support. The resultant carbon was denoted by HCMK-3. This was a key step in preparing a catalyst with highly dispersed $\mathrm{FeO}_{x}$ species. A large amount of oxygen-containing functional groups formed on the HCMK-3 surface. Table 1 shows that the amounts of functional groups on HCMK-3, including carboxylic, lactonic, and phenolic groups, were all higher than those on CMK-3. The total amount of functional groups was about $1.47 \mathrm{mmol} / \mathrm{g}$. The



Fig. 1. Schematic illustration of synthetic route for $\mathrm{FeO}_{x} / \mathrm{HCMK}-3$ preparation.

abundant functional groups endow the HCMK-3 support with a hydrophilic surface. This facilitates introduction of iron nitrate solution into the mesopores of the carbon support. The dried solid was calcined at $400{ }^{\circ} \mathrm{C}$ for $4 \mathrm{~h}$ in an Ar flow to give the $\mathrm{FeO}_{x} / \mathrm{HCMK}-3$ catalyst.

The XRD patterns show that $\mathrm{FeO}_{x} / \mathrm{HCMK}-3$ retains the ordered arrangement of the parent HCMK-3 support (Fig. 2a). The three diffraction peaks in the range $2 \theta=0.75^{\circ}-3^{\circ}$ can be indexed to the (100), (110), and (200) reflections of the HCMK-3 hexagonal space group. Wide-angle XRD patterns show that both samples have two broad diffraction peaks, centered at $24.5^{\circ}$ and $44^{\circ}$ (Fig. 2b), which are assigned to diffractions from the (002) and (100) graphite planes of the carbon supports [37]. No crystalline phase related to iron oxides was observed, indicating that the iron oxide particles are small or the degree of crystallization is low. The Raman spectra of $\mathrm{FeO}_{x} /$ HCMK-3 and HCMK-3 show two peaks, at 1358 and 1598 $\mathrm{cm}^{-1}$, which are assigned to the D and G bands of the carbon support (Fig. 2c) [38,39]. No peak below $1000 \mathrm{~cm}^{-1}$ attributable to crystalline iron oxides can be observed $[40,41]$; this also indicates that the iron oxide particles in $\mathrm{FeO}_{x} / \mathrm{HCMK} 3$ are small. The $\mathrm{N}_{2}$ adsorption-desorption isotherms show that $\mathrm{FeO}_{x} / \mathrm{HCMK}-3$ gives isotherms typical of an ordered mesostructure (type IV) with a well-defined step in the adsorption curve near $p / p_{0}=0.5$ (Fig. $2 \mathrm{~d}$ ). The surface area, pore volume, and pore size of $\mathrm{FeO}_{x} / \mathrm{HCMK}-3$ are similar to those of HCMK-3, indicating that the iron oxides do not block the mesopores of the CMK-3 support.

TEM images confirm that $\mathrm{FeO}_{x} / \mathrm{HCMK}-3$ retains the ordered structure of the CMK-3 support (Fig. 3a). No Fe particles were observed in the region examined, even at high resolution (Fig.

Table 1

Boehm titration results for CMK-3 and HCMK-3.

\begin{tabular}{lcccc}
\hline \multirow{2}{*}{ Sample } & \multicolumn{4}{c}{ Content of functional groups (mmol/g) } \\
\cline { 2 - 5 } & Carboxylic & Lactonic & Phenolic & Acidic \\
\hline CMK-3 & 0.01 & 0.11 & 0.12 & 0.24 \\
HCMK-3 & 0.24 & 0.34 & 0.89 & 1.47 \\
\hline
\end{tabular}



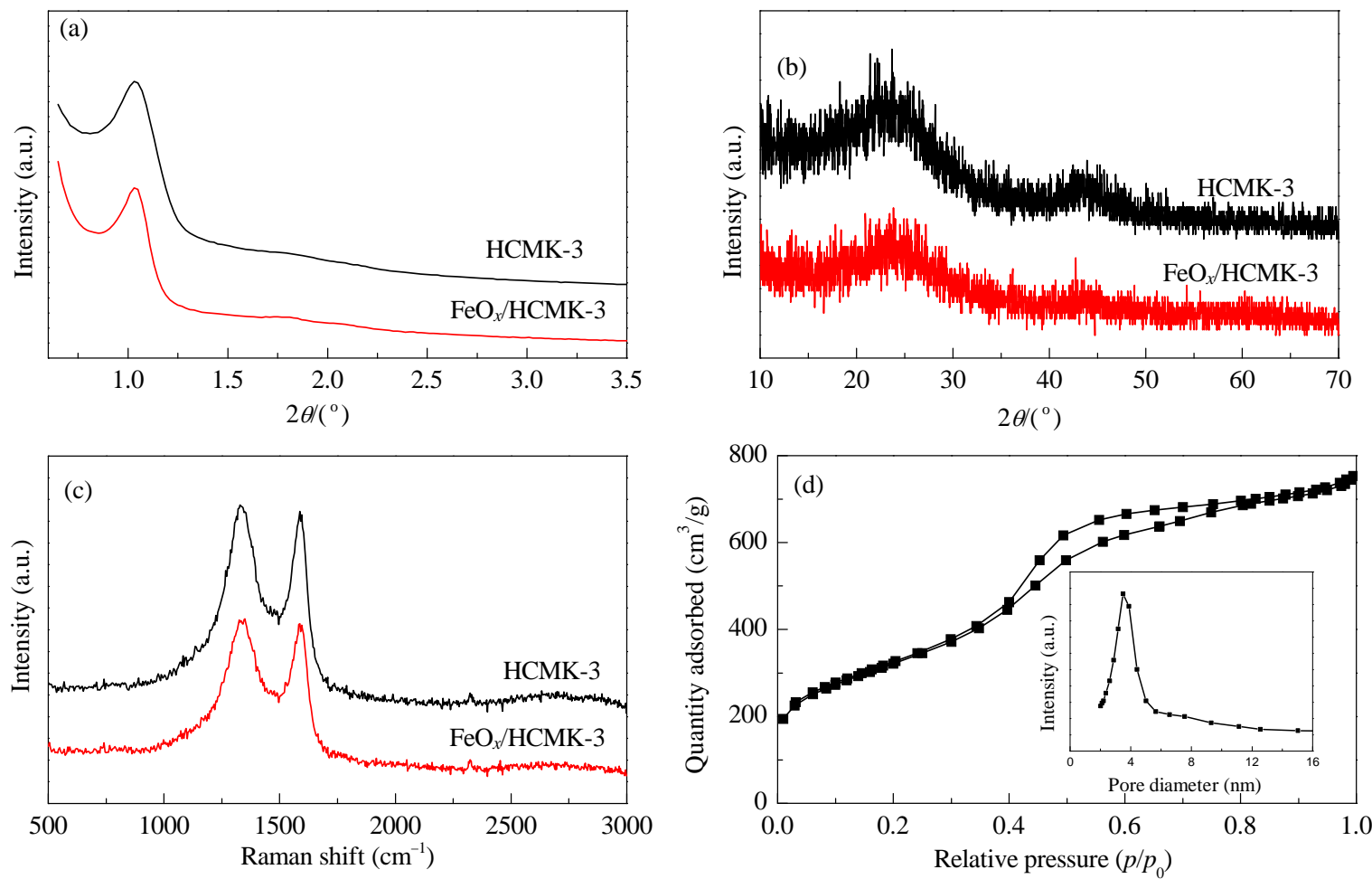

Fig. 2. Low-angle (a) and wide-angle (b) XRD patterns for $\mathrm{HCMK}^{-3}$ and $\mathrm{FeO}_{x} / \mathrm{HCMK}^{-3}$; (c) Raman spectra of $\mathrm{HCMK}-3$ and FeO $/ \mathrm{HCMK}-3$; (d) $\mathrm{N}_{2}$ adsorption-desorption isotherms of $\mathrm{FeO}_{x} / \mathrm{HCMK}-3$ (inset shows pore size distribution).

$3 \mathrm{~b}$ and $\mathrm{c}$ ). STEM and energy-dispersive X-ray mapping were performed to investigate iron oxide dispersion (Fig. 3d and e). The results show that Fe species are nearly homogeneously dispersed on the HCMK-3 surface, but the particle size still cannot be ascertained based on these measurements. A sample with a low $\mathrm{FeO}_{x}$ loading (0.25 wt\%) was prepared to clarify the $\mathrm{FeO}_{x}$ dispersed state on the $\mathrm{HCMK}-3$ surface. $\mathrm{FeO}_{x}$ particles still cannot be observed in the HRTEM image (not shown), but some light spots (about 2-3 nm) can be distinguished in the HAADF-STEM image (Fig. 3f). These results suggest that $\mathrm{FeO}_{x}$ species are present as two-dimensional or even sub-nano clusters. These clusters could be the constituent units of the highly dispersed $\mathrm{FeO}_{x}$ on the carbon support. The HRTEM and HAADF-STEM images together confirm that the $\mathrm{FeO}_{x}$ species are highly dispersed on the HCMK-3 support surface.

XPS shows that there are no obvious differences between the Fe $2 p$ binding energies of $\mathrm{FeO}_{x} / \mathrm{HCMK}-3$ and bulk $\mathrm{Fe}_{2} \mathrm{O}_{3}$ (Fig. 4a). The Fe $2 p_{1 / 2}$ and Fe $2 p_{3 / 2}$ peaks appear at 724.2 and $710.9 \mathrm{eV}$, respectively. This indicates that most of the Fe species are present in the iron oxides in the +3 valence state $[42,43]$. Clear differences can be observed in the $01 s$ spectra. The binding energies in the deconvoluted $01 s$ XPS spectrum are in according with those reported in the literature [44,45]. The $\mathrm{O} 1 \mathrm{~s}$ spectrum of bulk $\mathrm{Fe}_{2} \mathrm{O}_{3}$ can be deconvoluted into two peaks (Fig. 4b). Peak I, in the range $529.5-530.5 \mathrm{eV}$, is assigned to $\mathrm{O}^{2-}$ ions in the iron oxide lattice. Peak II, centered at about $532 \mathrm{eV}$, is related to oxygen in surface $\mathrm{OH}$ groups or oxygen vacancies in $\mathrm{Fe}_{2} \mathrm{O}_{3}$. The peak II/peak I area ratio is 0.21 for bulk $\mathrm{Fe}_{2} \mathrm{O}_{3}$. The $\mathrm{FeO}_{x} / \mathrm{HCMK} 3 \mathrm{O}$ 1s spectrum can be deconvoluted into three peaks. The new peak (peak III) at $534 \mathrm{eV}$ is attribut- ed to oxygen functional groups remaining on the catalyst surface. The peak II/peak I area ratio is 3.54 for $\mathrm{FeO}_{x} / \mathrm{HCMK}-3$, which is much higher than that for bulk $\mathrm{Fe}_{2} \mathrm{O}_{3}$. This is caused by the small size of the iron oxide particles and interactions between iron oxides and the carbon support.

Diffuse reflectance infrared Fourier transform (DRIFT) spectra show that some oxygen-containing groups remain on the $\mathrm{FeO}_{x} / \mathrm{HCMK} 3$ surface (Fig. 5a). Further FT-IR spectra were obtained to clarify whether the Fe species were located in iron oxides or present as $\mathrm{Fe}^{3+}$ ions coordinated with these functional groups. A sample consisting of $\mathrm{Fe}^{3+}$ ions supported on HCMK-3 (denoted by Fe-HCMK-3) was prepared via the same impregnation method as was used to prepare $\mathrm{FeO}_{x} / \mathrm{HCMK}-3$, with $\mathrm{HNO}_{3}$-treated $\mathrm{CMK}-3$ as a support. The Fe species loading was the same as that for $\mathrm{FeO}_{x} / \mathrm{HCMK}-3$. The difference is that after impregnation, the sample was dried in an oven at $80^{\circ} \mathrm{C}$ for $12 \mathrm{~h}$ to obtain Fe-HCMK-3, whereas further thermal treatment at $400{ }^{\circ} \mathrm{C}$ in an Ar flow for $4 \mathrm{~h}$ is needed to obtain $\mathrm{FeO}_{x} / \mathrm{HCMK}-3$. The peak at $469 \mathrm{~cm}^{-1}$ in the FT-IR spectrum of $\mathrm{FeO}_{x} / \mathrm{HCMK}^{-3}$ (Fig. $5 b$ ) can be attributed to the stretching vibration of $\mathrm{Fe}-\mathrm{O}$, similar to that of $\mathrm{Fe}_{2} \mathrm{O}_{3}$. However, this signal is different in the Fe-HCMK-3 spectrum. A combination of the FT-IR and XPS results confirms that $\mathrm{Fe}$ is mainly located in iron oxide species (i.e., $\mathrm{FeO}_{x}$ ). The formation of $\mathrm{FeO}_{x}$ species in $\mathrm{FeO}_{x} / \mathrm{HCMK}-3$ is a result of the high treatment temperature. The oxygen-containing functional groups in HCMK-3 can interact with these two-dimensional $\mathrm{FeO}_{x}$ species.

The $\mathrm{H}_{2}$-TPR profiles (Fig. 6) show that the iron oxide species in $\mathrm{FeO}_{x} / \mathrm{HCMK}-3$ are more reducible than those in bulk $\mathrm{Fe}_{2} \mathrm{O}_{3}$. There are three reduction peaks present in the profile of bulk 

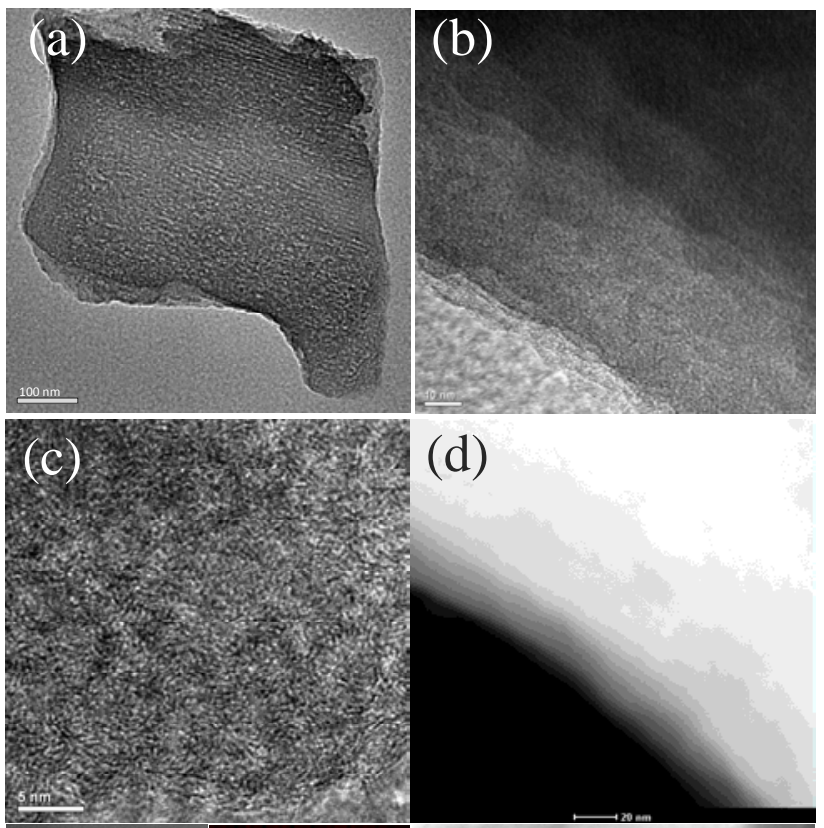

(d)
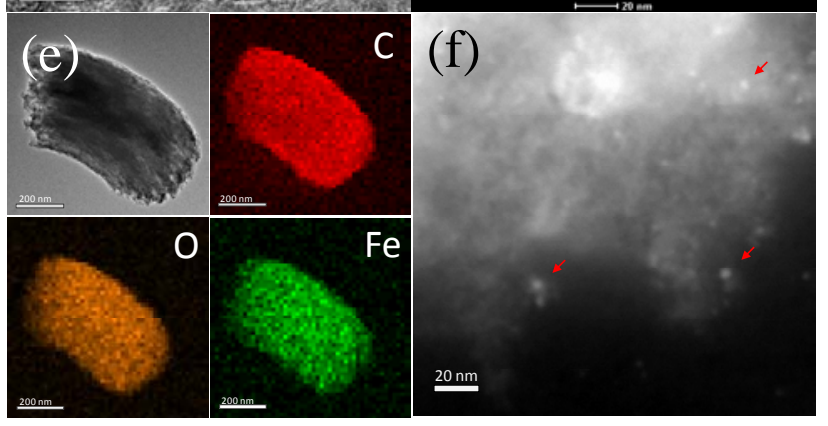

Fig. 3. TEM (a), HRTEM (b, c), HAADF-STEM (d), and energy-dispersive X-ray mapping images (e) of $\mathrm{FeO}_{x} / \mathrm{HCMK}-3$; (f) HAADF-STEM image of $0.25 \mathrm{wt} \% \mathrm{FeO}_{x} / \mathrm{HCMK}-3$ catalyst.

$\mathrm{Fe}_{2} \mathrm{O}_{3}$. The narrow peak (centered at $430{ }^{\circ} \mathrm{C}$ ) can be ascribed to the reduction of $\mathrm{Fe}_{2} \mathrm{O}_{3}$ to $\mathrm{Fe}_{3} \mathrm{O}_{4}$. The two overlapping peaks in the range $450-800{ }^{\circ} \mathrm{C}$ can be ascribed to further reduction to $\mathrm{FeO} / \mathrm{Fe}$ species $[46,47]$. For $\mathrm{FeO}_{x} / \mathrm{HCMK}-3$, only one broad peak is present in the range $200-600{ }^{\circ} \mathrm{C}$. The start and center of this peak are clearly at lower temperatures than those for bulk $\mathrm{Fe}_{2} \mathrm{O}_{3}$, confirming the high reducibility of $\mathrm{FeO}_{x} / \mathrm{HCMK}-3$. The amounts of $\mathrm{H}_{2}$ consumed by $\mathrm{FeO}_{x} / \mathrm{HCMK}-3$ and $\mathrm{Fe}_{2} \mathrm{O}_{3}$ during

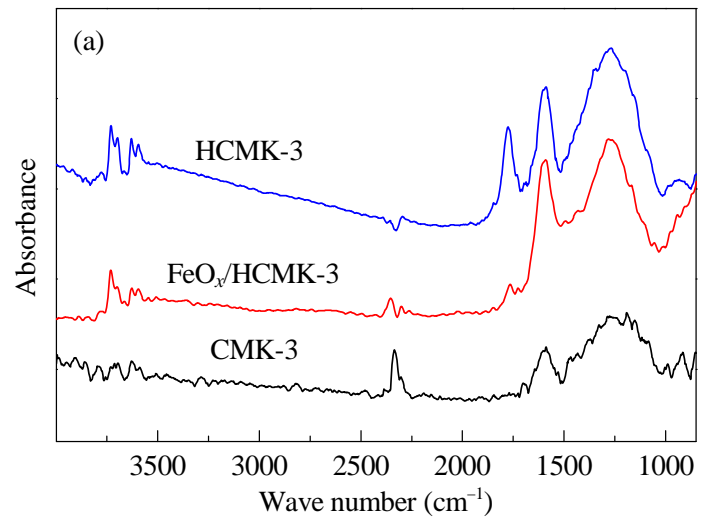

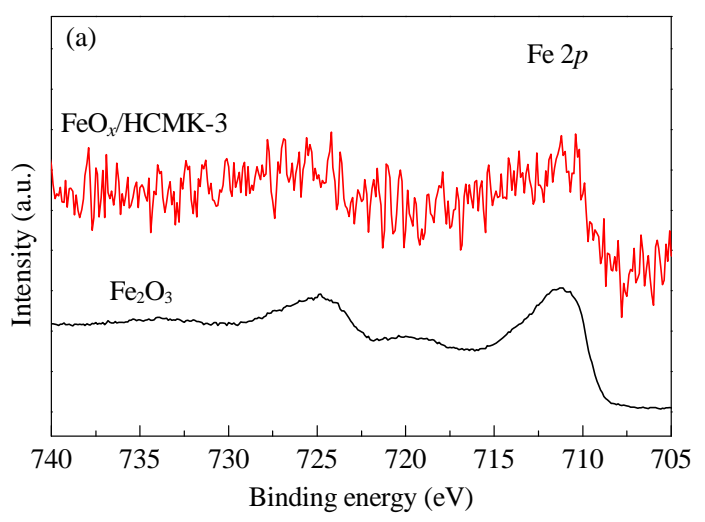

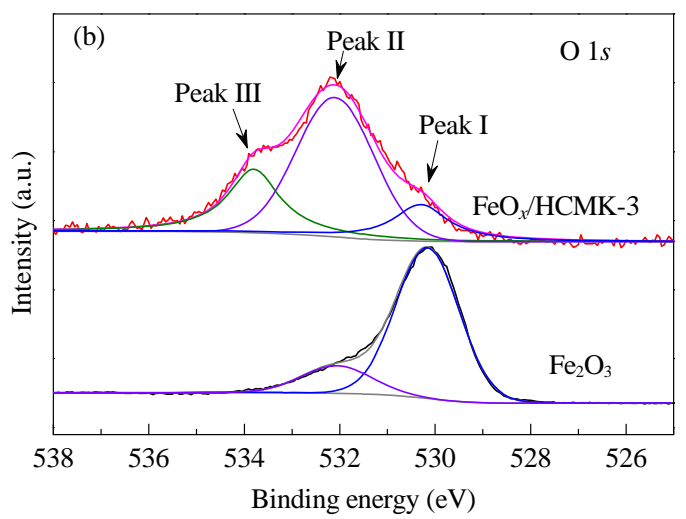

Fig. 4. $\mathrm{Fe} 2 p$ (a) and $\mathrm{O} 1 s$ (b) XPS spectra of $\mathrm{FeO}_{x} / \mathrm{HCMK}-3$ and bulk $\mathrm{Fe}_{2} \mathrm{O}_{3}$.

TPR were 2.13 and $18.10 \mathrm{mmol} / \mathrm{g}$, respectively. The $\mathrm{FeO}_{x}$ content in $\mathrm{FeO}_{x} / \mathrm{HCMK} 3$ was $5 \mathrm{wt} \%$, therefore the stoichiometric consumption of $\mathrm{H}_{2}$ by $\mathrm{FeO}_{x}$ should be $0.93 \mathrm{mmol} / \mathrm{g}$, which is lower than the actual amount of $\mathrm{H}_{2}$ consumed (2.13 mmol/g). A combination of the $\mathrm{H}_{2}$-TPR, XPS, and DRIFT results shows that additional $\mathrm{H}_{2}$ is consumed $(1.2 \mathrm{mmol} / \mathrm{g}$ ) because of the presence of oxygen-containing functional groups in $\mathrm{FeO}_{x} / \mathrm{HCMK}-3$. The quantity of reduced functional groups in $\mathrm{FeO}_{x} / \mathrm{HCMK}-3$ was determined based on $\mathrm{H}_{2}$-TPR of HCMK-3. The results show that $\mathrm{H}_{2}$ consumption by HCMK-3 was about $1.08 \mathrm{mmol} / \mathrm{g}$, which is consistent with $\mathrm{H}_{2}$ consumption by the carbon support in $\mathrm{FeO}_{x} / \mathrm{HCMK}-3$ (1.2 mmol/g).

These results show that oxygen functional groups play im-

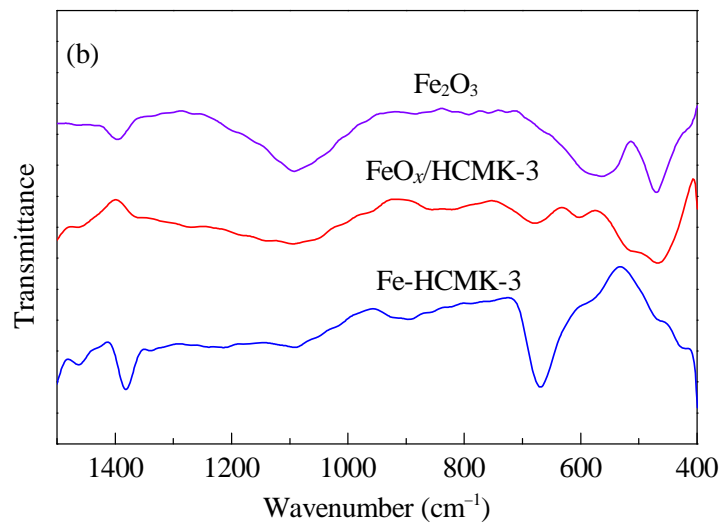

Fig. 5. (a) DRIFT spectra of CMK-3, $\mathrm{HCMK}-3$, and $\mathrm{FeO}_{x} / \mathrm{HCMK}-3$; (b) FT-IR spectra of $\mathrm{FeO}_{x} / \mathrm{HCMK} 3$, Fe-HCMK-3, and $\mathrm{Fe}_{2} \mathrm{O}_{3}$. 


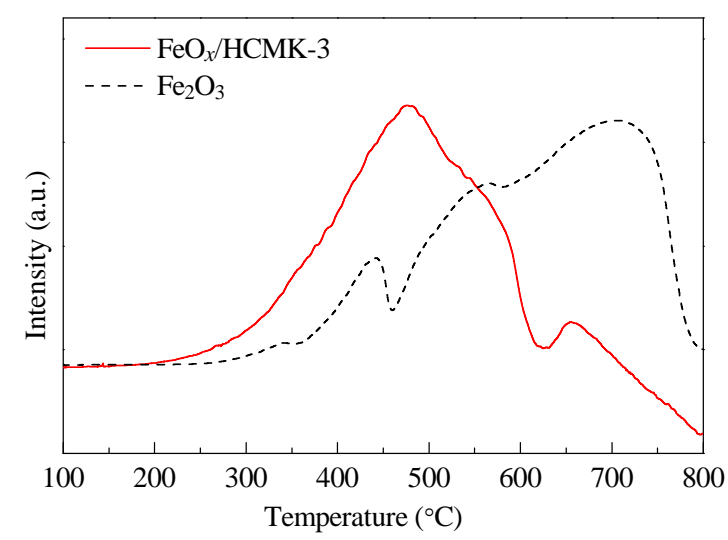

Fig. 6. $\mathrm{H}_{2}$-TPR profiles of $\mathrm{FeO}_{x} / \mathrm{HCMK}-3$ and bulk $\mathrm{Fe}_{2} \mathrm{O}_{3}$.

portant roles in the formation of highly dispersed iron oxide species. They render the HCMK-3 support surface negatively charged. Zeta-potential measurements show that HCMK-3 is negatively charged at pH 1.0-8.0 (Fig. 7). Untreated CMK-3 is positively charged at $\mathrm{pH}$ less than $5.1 . \mathrm{FeO}_{x} / \mathrm{HCMK} 3$ was prepared by impregnation with $\mathrm{Fe}\left(\mathrm{NO}_{3}\right)_{3}$ aqueous solution. The $\mathrm{pH}$ of the $\mathrm{Fe}^{3+}$-containing solution was 1.65 (Fig. 7). Under these preparation conditions, there is an electrostatic force between the positively charged metal ions and negatively charged carbon surface (Fig. 1). This could be the main reason for the homogeneous dispersion of Fe ions on the carbon surface. In the subsequent thermal treatment, these surface oxygen functional groups provide strongly active sites for anchoring $\mathrm{FeO}_{x}$ species, and suppress iron oxide aggregation.

\subsection{Catalytic performance}

Fig. 8 shows the catalytic activity of $\mathrm{FeO}_{x} / \mathrm{HCMK}-3$ in the oxidative coupling of benzyl alcohol and aniline to an imine at $80{ }^{\circ} \mathrm{C}$. The imine was identified using gas chromatography-mass spectrometry. For comparison, the reaction was also performed using bulk $\mathrm{Fe}_{2} \mathrm{O}_{3}$ and HCMK-3. The activity of bulk $\mathrm{Fe}_{2} \mathrm{O}_{3}$ was low. Only a $13.2 \%$ yield of imine was obtained after reaction for $8 \mathrm{~h}$ at $80^{\circ} \mathrm{C}$. The HCMK-3 support was almost inactive under the test conditions. For $\mathrm{FeO}_{x} / \mathrm{HCMK}-3$, the yield



Fig. 7. Zeta-potential profiles for CMK-3 and HCMK-3; pH is the value for impregnation process, i.e., iron nitrate solution containing HCMK-3.

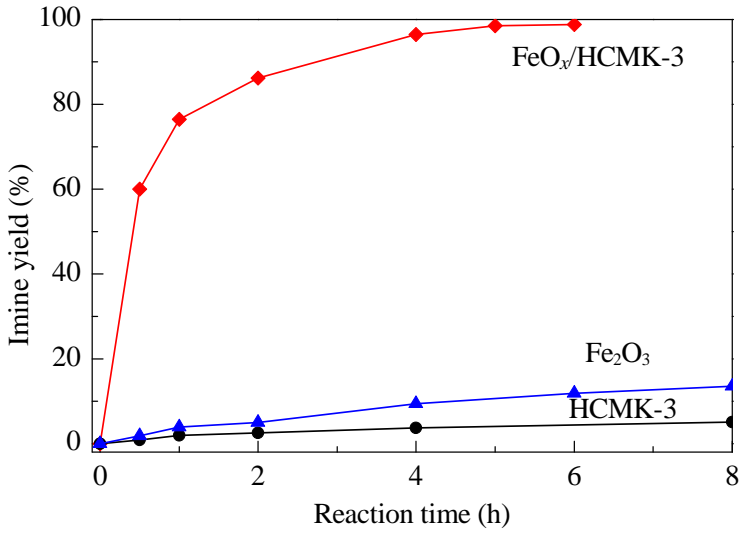

Fig. 8. Time dependences of imine formation from aerobic oxidative coupling of benzyl alcohol and aniline over $\mathrm{FeO}_{x} / \mathrm{HCMK}-3$, bulk $\mathrm{Fe}_{2} \mathrm{O}_{3}$, and HCMK-3. Reaction conditions: benzyl alcohol $1 \mathrm{mmol}$, aniline 2 mmol, catalyst $0.3 \mathrm{~g}$, toluene $10 \mathrm{~mL}, 80^{\circ} \mathrm{C}$, air $1 \mathrm{bar}$.

of imine after reaction for $6 \mathrm{~h}$ was $98.8 \%$. The TOF for $\mathrm{FeO}_{x} / \mathrm{HCMK}-3$ in the initial stage was $2.9 \mathrm{~h}^{-1}$. The catalytic performance of $\mathrm{FeO}_{x} / \mathrm{HCMK}-3$ at $60{ }^{\circ} \mathrm{C}$ was also investigated for comparison with those of other reported catalytic systems. The TOF was $0.6 \mathrm{~h}^{-1}$. Comparisons with results reported in the literature $[19,25,26]$ show that this TOF is higher than those for non-noble-metal oxide catalysts (e.g., $\mathrm{CeO}_{2}$ and $\mathrm{MnO}_{x} / \mathrm{HAP}$ ), but a little lower than those of supported Au catalysts under similar reaction conditions. The reaction was also performed using equimolar amounts of the alcohol and amine. A 78.4\% yield of the imine was obtained after reaction for $8 \mathrm{~h}$. All these results indicate that $\mathrm{FeO}_{x} / \mathrm{HCMK}-3$ is an effective catalyst for imine formation.

Multiple aerobic oxidation cycles were performed to examine the recoverability of $\mathrm{FeO}_{x} / \mathrm{HCMK}-3$ (Fig. 9). The catalyst retained high activity after five cycles, with only $3 \%$ and $5 \%$ decreases in the third and fifth cycles compared with the first one. Loss of Fe from the catalyst to the reaction mixture was determined using ICP-AES. Trace amounts of Fe $(0.02 \mathrm{ppm}$, $0.02 \%$ of total $\mathrm{Fe}$ ) were detected, indicating that Fe active sites



Fig. 9. Reusability of $\mathrm{FeO}_{x} / \mathrm{HCMK}-3$ in imine synthesis by aerobic oxidative coupling of benzyl alcohol and aniline. Reaction conditions: benzyl alcohol $1 \mathrm{mmol}$, aniline $2 \mathrm{mmol}$, catalyst $0.3 \mathrm{~g}$, toluene $10 \mathrm{~mL}, 80^{\circ} \mathrm{C}$, air $1 \mathrm{bar}, 3 \mathrm{~h}$. Recovered catalysts were treated under $\mathrm{Ar}$ at $400^{\circ} \mathrm{C}$ for $1 \mathrm{~h}$. 
were not lost. The XRD patterns show that there was no aggregation of iron oxide species in the used $\mathrm{FeO}_{x} / \mathrm{HCMK}-3$. All these results suggest that iron oxide active sites are stable in the $\mathrm{FeO}_{x} / \mathrm{HCMK}-3$ catalyst. The decrease in the imine yield was mainly caused by loss of catalyst in the recycling process. The catalyst was recycled by filtration and then thermally treated at $400{ }^{\circ} \mathrm{C}$ for $1 \mathrm{~h}$ under Ar to remove adsorbed reagents. Catalyst loss (about 7\%) is inevitable during this process.

Experiments were performed to identify the active sites in $\mathrm{FeO}_{x} / \mathrm{HCMK}-3$ (Table 2). When $\mathrm{Fe}\left(\mathrm{NO}_{3}\right)_{3}$ was used as the catalyst, the yield of imine after reaction for $8 \mathrm{~h}$ was $1.8 \%$. Even in the co-presence of $\mathrm{Fe}\left(\mathrm{NO}_{3}\right)_{3}$ and HCMK-3, the imine yield was only $5.0 \%$. These results differ from those reported by Zhang et al. [48], mainly because different reaction conditions were used. Under their reaction conditions, $\mathrm{Fe}\left(\mathrm{NO}_{3}\right)_{3}$ shows moderate activity in imine synthesis and the activity can be greatly enhanced by addition of 2,2,6,6-tetramethyl-1-piperidinyloxy [48]. We also investigated the catalytic performance of Fe-HCMK-3. An imine yield of $24.6 \%$ was obtained over Fe-HCMK-3 after reaction for $8 \mathrm{~h}$; this is much lower than the yield achieved using $\mathrm{FeO}_{x} / \mathrm{HCMK}-3$. Loss of Fe into the reaction mixture was detected using ICP-AES; the amount was about $33.65 \mathrm{ppm}$, which is $3.2 \%$ of the total amount of Fe loaded on Fe-HCMK-3. All these results suggest that $\mathrm{Fe}^{3+}$ ions or coordinated $\mathrm{Fe}$ species were not active in the imine synthesis reaction. Supported $\mathrm{FeO}_{x}$ species were the effective and stable active sites. The highly dispersed $\mathrm{FeO}_{x}$ species on the HCMK-3 surface could affect the redox properties of the $\mathrm{FeO}_{x} / \mathrm{HCMK}-3$ catalyst. The reducibility of these iron oxide species could be responsible for the high activity in this reaction.

The general applicability of the $\mathrm{FeO}_{x} / \mathrm{HCMK}-3$ catalyst was also investigated. Eleven imines were obtained by oxidative coupling of amines with various alcohols. Table 3 (entries 1-7) shows that the $\mathrm{FeO}_{x} / \mathrm{HCMK}-3$ catalyst is active in reactions using benzyl alcohol derivatives with either electron-rich or electron-poor substituents, especially 4-methylbenzyl alcohol, 4-methoxybenzyl alcohol, and 4-isopropylbenzyl alcohol (the imine yields were $93.2 \%, 90.7 \%$, and $84.2 \%$, respectively, after reaction for $8 \mathrm{~h}$ ). $\mathrm{FeO}_{x} / \mathrm{HCMK}-3$ also catalyzed the reaction of phenethyl alcohol and allylic alcohols (e.g., trans-2-hexenol) with aniline to give the corresponding imines when the reaction temperature and time were increased (Table 3, entries 8 and 9). Table 3 shows that $\mathrm{FeO}_{x} / \mathrm{HCMK}-3$ is active in the aerobic oxidative coupling of aliphatic amines (e.g., cyclohexylamine

\section{Table 2}

Imine synthesis by oxidative coupling of benzyl alcohol and aniline over various catalysts.

\begin{tabular}{lccc}
\hline Entry & Catalyst & Time $(\mathrm{h})$ & Yield (\%) \\
\hline 1 & $\mathrm{FeO} \mathrm{O}_{x} / \mathrm{HCMK}-3$ & 6 & 98.6 \\
2 & None & 8 & 0.9 \\
$3^{*}$ & $\mathrm{Fe}\left(\mathrm{NO}_{3}\right)_{3}$ & 8 & 1.8 \\
$4^{*}$ & $\mathrm{Fe}\left(\mathrm{NO}_{3}\right)_{3}+\mathrm{HCMK}-3$ & 8 & 5.0 \\
5 & $\mathrm{Fe}-\mathrm{HCMK}-3$ & 8 & 24.6 \\
6 & $\mathrm{Fe}_{2} \mathrm{O}_{3}$ & 8 & 13.2 \\
7 & $\mathrm{HCMK} 3$ & 8 & 5.1 \\
\hline
\end{tabular}

Reaction conditions: benzyl alcohol $1 \mathrm{mmol}$, aniline $2 \mathrm{mmol}$, catalyst 0.3 g, toluene $10 \mathrm{~mL}, 80^{\circ} \mathrm{C}$, air 1 bar. ${ }^{*}$ The amount of $\mathrm{Fe}\left(\mathrm{NO}_{3}\right)_{3}$ was calculated based on the Fe content in $\mathrm{FeO}_{x} / \mathrm{HCMK}-3$.
Table 3

Aerobic oxidative coupling of various alcohols and anilines over $\mathrm{FeO}_{x} / \mathrm{HCMK}-3$ catalyst.

Time (h)

Reaction conditions: alcohol $1 \mathrm{mmol}$, amine $2 \mathrm{mmol}$, catalyst $0.3 \mathrm{~g}$, toluene $10 \mathrm{~mL}, 80^{\circ} \mathrm{C}$, air 1 bar. ${ }^{*}$ Temperature: $100^{\circ} \mathrm{C}$.

and $n$-butylamine) with benzyl alcohol (Table 3, entries 10 and 11). These results clearly show that $\mathrm{FeO}_{x} / \mathrm{HCMK}-3$ is an efficient catalyst in oxidative coupling reactions.

Three additional experiments were performed to clarify the reaction mechanism over $\mathrm{FeO}_{x} / \mathrm{HCMK}-3$; the results are shown in Fig. 10. Fig. 10a shows that the oxygen species in $\mathrm{FeO}_{x} / \mathrm{HCMK} 3$ are active in the aerobic oxidative reaction. Even without the presence of $\mathrm{O}_{2}$, an $8.7 \%$ yield of imine was obtained after reaction for $8 \mathrm{~h}$ at $80^{\circ} \mathrm{C}$. This experiment was performed in a Schlenk tube (see the experimental section for details). The $\mathrm{FeO}_{x} / \mathrm{HCMK}-3$ catalyst was first degassed at $80{ }^{\circ} \mathrm{C}$ for $1.5 \mathrm{~h}$ under vacuum to remove adsorbed $\mathrm{O}_{2}$. After adding the reactants and solvent, the system was further degassed and then balanced with high-purity $\mathrm{N}_{2}$. All these treatments were performed to ensure the removal of molecular $\mathrm{O}_{2}$ from the system. This result shows that the oxygen species in $\mathrm{FeO}_{x} / \mathrm{HCMK}-3$ participate in the reaction. The oxidative coupling of alcohols and amines on $\mathrm{FeO}_{x} / \mathrm{HCMK}-3$ occur via a redox mechanism $[25,26]$. During imine synthesis over $\mathrm{FeO}_{x} / \mathrm{HCMK}-3$, benzaldehyde was detected in the initial stage and the amount slowly decreased with time (Fig. 10b). This suggests that benzalde- 

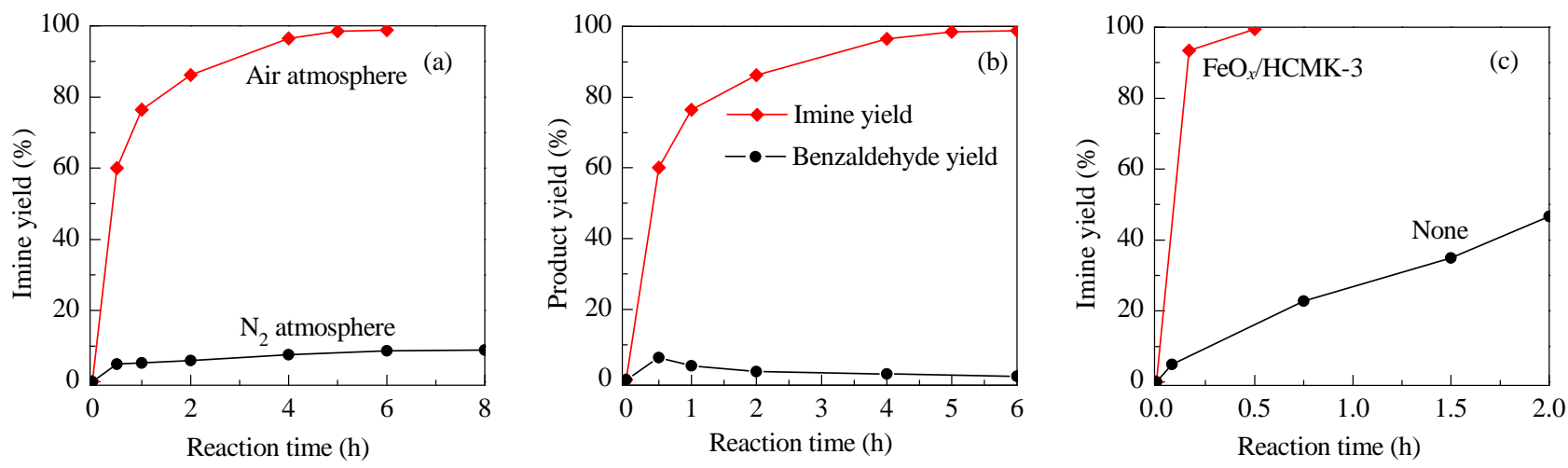

Fig. 10. (a) Effects of catalytic conditions on performance of $\mathrm{FeO}_{x} / \mathrm{HCMK}-3$ in imine formation by aerobic oxidative coupling of benzyl alcohol and aniline. Reaction conditions: benzyl alcohol $1 \mathrm{mmol}$, aniline $2 \mathrm{mmol}$, catalyst $0.3 \mathrm{~g}$, toluene $10 \mathrm{~mL}, 80^{\circ} \mathrm{C}$, air or $\mathrm{N}_{2} 1 \mathrm{bar}$. (b) Time dependence of imine formation by oxidative coupling of benzyl alcohol and aniline over $\mathrm{FeO}_{x} / \mathrm{HCMK}-3$. Reaction conditions: benzyl alcohol $1 \mathrm{mmol}$, aniline $2 \mathrm{mmol}$, catalyst $0.3 \mathrm{~g}$, toluene $10 \mathrm{~mL}, 80{ }^{\circ} \mathrm{C}$, air 1 bar. (c) Time dependences of imine formation by coupling of benzaldehyde and aniline with and without $\mathrm{FeO}_{x} / \mathrm{HCMK}-3$ catalyst. Reaction conditions: benzaldehyde $1 \mathrm{mmol}$, aniline $2 \mathrm{mmol}$, catalyst $0.3 \mathrm{~g}$, toluene $10 \mathrm{~mL}, 80{ }^{\circ} \mathrm{C}$, air $1 \mathrm{bar}$.

hyde might be an intermediate and that the reaction proceeds in two consecutive steps: (1) oxidative dehydrogenation of the alcohol to benzaldehyde and (2) imine formation by reaction of benzaldehyde with aniline.

We recently reported that $\mathrm{FeO}_{x} / \mathrm{HCMK}-3$ catalyzes the oxidation of benzyl alcohol to benzaldehyde with air as the oxygen source [33]. Benzyl alcohol conversion of $72 \%$ was observed after reaction for $8 \mathrm{~h}$. In the imine synthesis, benzyl alcohol conversion improved to $98.8 \%$ after reaction for $6 \mathrm{~h}$. The second step in imine formation accelerates the conversion of benzyl alcohol. Fig. 10c shows that $\mathrm{FeO}_{x} / \mathrm{HCMK} 3$ efficiently catalyzes imine synthesis from benzaldehyde and aniline. The reaction rate is $372.8 \mathrm{mmol} \mathrm{h}^{-1} \mathrm{~g}^{-1}$ (calculated based on iron oxide sites), which is 4.5 times higher than that for imine formation from benzyl alcohol and aniline $\left(82.0 \mathrm{mmol} \mathrm{h}^{-1} \mathrm{~g}^{-1}\right)$. This confirms that oxidative dehydrogenation of alcohol is the rate-determining step in the reaction. Based on the above results and related literature reports [49,50], a plausible reaction mechanism for imine formation from an alcohol and aniline on $\mathrm{FeO}_{x} /$ HCMK-3 is proposed (Scheme 1). Oxidative dehydrogena- tion of benzyl alcohol by oxygen species occurs at the redox sites of $\mathrm{FeO}_{x} / \mathrm{HCMK}-3$. Iron is reduced from valence +3 to +2 . The produced benzaldehyde reacts with aniline over $\mathrm{FeO}_{x} / \mathrm{HCMK}-3$ to afford the corresponding imine. $\mathrm{FeO}_{x} /$ HCMK-3 is regenerated by oxidation of the reduced $\mathrm{FeO}_{x} / \mathrm{HCMK}-3$ with $\mathrm{O}_{2}$.

\section{Conclusions}

$\mathrm{FeO}_{x} / \mathrm{HCMK}-3$ with highly dispersed iron oxide species shows high activity and recyclability in aerobic oxidative coupling of alcohols and amines to imines. The excellent catalytic performance of $\mathrm{FeO}_{x} / \mathrm{HCMK}-3$ is ascribed to its high reducibility. The lattice oxygens in $\mathrm{FeO}_{x} / \mathrm{HCMK}-3$ can participate in imine synthesis, and the reaction follows a redox mechanism over $\mathrm{FeO}_{x} / \mathrm{HCMK}-3$. Two consecutive steps are involved in the reaction: oxidative dehydrogenation of an alcohol to an aldehyde and coupling of the aldehyde with an amine to an imine. Oxidative dehydrogenation of alcohol is the rate-determining step in the reaction.
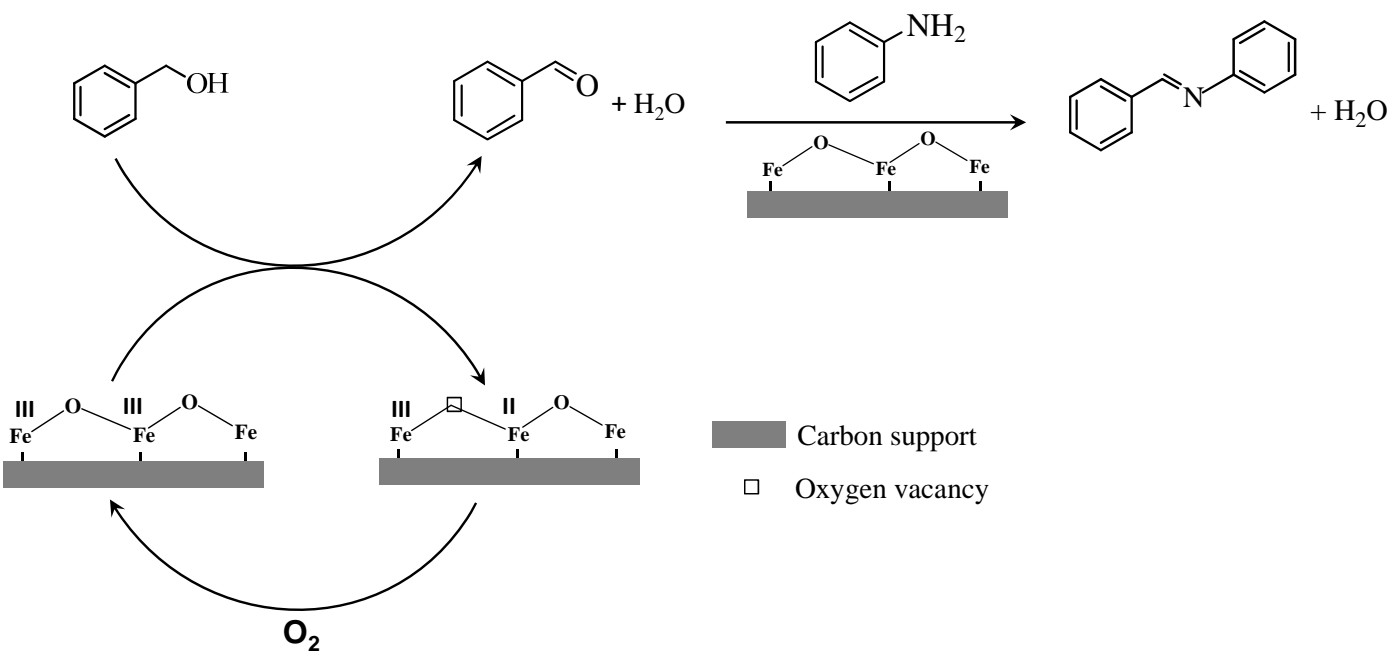

Scheme 1. Proposed reaction mechanism for imine formation over $\mathrm{FeO}_{x} / \mathrm{HCMK}-3$. 


\section{References}

[1] Z. B. Han, Z. Wang, X. M. Zhang, K. L. Ding, Angew. Chem. Int. Ed, 2009, 48, 5345-5349.

[2] A. J. A. Watson, J. M. J. Williams, Science, 2010, 329, 635-636.

[3] J. Gawronski, N. Wascinska, J. Gajewy, Chem. Rev., 2008, 108, 5227-5252.

[4] S. I. Murahashi, Angew. Chem. Int. Ed., 1995, 34, 2443-2465.

[5] J. F. Soulé, H. Miyamura, S. Kobayashi, Asian J. Org. Chem., 2012, 1, 319-321.

[6] R. D. Patil, S. Adimurthy, Asian J. Org. Chem., 2013, 2, 726-744.

[7] V. Kumar, S. Sharma, U. Sharma, B. Singh, N. Kumar, Green Chem., 2012,14, 3410-3414.

[8] L. Ravishankar, S. A. Patwe, N. Gosarani, A. Roy, Synth. Commun., 2010, 40, 3177-3180.

[9] J. S. M. Samec, A. H. Éll, J. E. Bäckvall, Chem. Eur. J, 2001, 11, 2327-2334.

[10] B. Chen, L. Y. Wang, S. Gao, ACS Catal, 2015, 5, 5851-5876.

[11] Q. Kang, Y. G. Zhang, Green Chem., 2012, 14, 1016-1019.

[12] S. Sithambaram, R. Kumar, Y. C. Son, S. L. Suib, J. Catal., 2008, 253, 269-277.

[13] R. Cano, D. J. Ramón, M. Yus, J. Org. Chem., 2011, 76, 5547-5557.

[14] Z. X. Zhang, Y. H. Wang, M. Wang, J. M. Lü, L. H. Li, Z. Zhang, M. R. Li, J. Y. Jiang, F. Wang, Chin. J. Catal., 2015, 36, 1623-1630.

[15] H. W. Tian, X. C. Yu, Q. Li, J. X. Wang, Q. Xu, Adv. Synth. Catal., 2012, 354, 2671-2677.

[16] B. Gnanaprakasam, J. Zhang, D. Milstein, Angew. Chem., 2010, 122, 1510-1513.

[17] J. F. Soulé, H. Miyamura, S. Kobayashi, J. Am. Chem. Soc., 2011, 133, 18550-18553.

[18] L. Tang, H. Y. Sun, Y. F. Li, Z. G. Zha, Z. Y. Wang, Green Chem., 2012, 14, 3423-3428.

[19] H. Sun, F. Z. Su, J. Ni, Y. Cao, H. Y. He, K. N. Fan, Angew. Chem. Int. Ed., 2009, 48, 4390-4393.

[20] W. He, L. D. Wang, C. Y. Sun, K. K. Wu, S. B. He, J. P. Chen, P. Wu, Z. K. Yu, Chem. Eur. J., 2011, 17, 13308-13317.

[21] D. Gnanamgari, E. L. O. Sauer, N. D. Schley, C. Butler, C. D. Incarvito, R. H. Crabtree, Organometallics, 2009, 28, 321-325.

[22] A. Corma, T. Ródenas, M. J. Sabater, Chem. Eur. J., 2010, 16, 254-260

[23] S. Kegnaes, J. Mielby, U. V. Mentzel, C. H. Christensen, A. Riisager, Green Chem., 2010, 12, 1437-1441.

[24] L. L. Zhang, W. T. Wang, A. Q. Wang, Y. T. Cui, X. F. Yang, Y. Q.
Huang, X. Y. Liu, W. G. Liu, J. Y. Son, H. Oji, T. Zhang, Green Chem., 2013, 15, 2680-2684.

[25] M. Tamura, K. Tomishige, Angew. Chem. Int. Ed., 2015, 54, 864-867.

[26] B. Chen, J. Li, W. Dai, L. Y. Wang, S. Gao, Green Chem., 2014, 16, 3328-3334.

[27] L. Y. Wang, B. Chen, L. H. Ren, H. Y. Zhang, Y. Lü, S. Gao, Chin. J. Catal., 2015, 36, 19-23.

[28] A. H. Lu, J. J. Nitz, M. Comotti, C. Weidenthaler, K. Schlichte, C. W. Lehmann, O. Terasaki, F. Schüth, J. Am. Chem. Soc., 2010, 132, 14152-14162.

[29] H. M. Torres Galvis, J. H. Bitter, C. B. Khare, M. Ruitenbeek, A. I. Dugulan, K. P. de Jong, Science, 2012, 355, 835-838.

[30] Z. X. Wu, W. Li, P. A. Webley, D. Y. Zhao, Adv. Mater, 2012, 24, 485-491.

[31] A. R. Rajenahally, A. E. Surkus, H. Junge, M. M. Pohl, J. Radnik, J. Rabeah, H. Huan, V. Schünemann, A. Brückner, M. Beller, Science, 2013, 342, 1073-1076.

[32] S. A. Cotton, Annu. Rep. Prog. Chem., Sect. A, 2005, 101, 208-230.

[33] L. L. Geng, X. Y. Zhang, W. X. Zhang, M. J. Jia, G. Liu, Chem. Commun., 2014, 50, 2965-2967.

[34] L. L. Geng, M. Zhang, W. X. Zhang, M. J. Jia, W. F. Yan, G. Liu, Catal. Sci. Technol., 2015, 5, 3097-3102.

[35] D. Y. Zhao, J. L. Feng, Q. S. Huo, N. Melosh, G. H. Fredrickson, B. F. Chmelka, G. D. Stucky, Science, 1998, 279, 548-552.

[36] S. Jun, S. H. Joo, R. Ryoo, M. Kruk, M. Jaroniec, Z. Liu, T. Ohsuna, O. Terasaki, J. Am. Chem. Soc., 2000, 122, 10712-10713.

[37] G. Liu, Y. Liu, Z. L. Wang, X. Z. Liao, S. J. Wu, W. X. Zhang, M. J. Jia, Microporous Mesoporous Mater., 2008, 116, 439-444.

[38] L. L. Geng, S. J. Wu, Y. C. Zou, M. J. Jia, W. X. Zhang, W. F. Yan, G. Liu, J. Colloid Interface Sci., 2014, 421, 71-77.

[39] M. Zhang, W. C. Zhu, G. Liu, X. Y. Zhang, Y. H. Zu, W. X. Zhang, W. F. Yan, M. J. Jia, Chin. J. Catal., 2012, 33, 465-472.

[40] X. Zhang, Y. A. Niu, X. D. Meng, Y. Li, J. D. Zhao, CrystEngComm, 2013, 15, 8166-8172.

[41] J. L. Tu, M. Y. Ding, Q. Zhang, Y. L. Zhang, C. G. Wang, T. J. Wang, L. L. Ma, X. J. Li, ChemCatChem, 2015, 7, 2323-2327.

[42] J. Yang, H. W. Zhang, M. H. Yu, I. Emmanuelawati, J. Zou, Z. G. Yuan, C. Z. Yu, Adv. Funct. Mater., 2014, 24, 1354-1363.

[43] M. Monti, B. Santos, A. Mascaraque, O. R. Figuera, M. A. Niño, T. O. Menteş, A. Locatelli, K. F. McCarty. J. F. Marco, J. de la Figuera, J. Phys. Chem. C, 2012, 116, 11539-11547.

[44] M. D. Sánchez, P. Chen, T. Reinecke, M. Muhler, W. Xia,

\section{Graphical Abstract}

Chin. J. Catal., 2016, 37: 1451-1460 doi: 10.1016/S1872-2067(16)62506-8

Aerobic oxidative coupling of alcohols and amines to imines over iron catalysts supported on mesoporous carbon

Longlong Geng, Jinling Song, Bin Zheng, Shujie Wu, Wenxiang Zhang, Mingjun Jia, Gang Liu*

Jilin University

Mesoporous-carbon-supported iron oxide is a highly efficient and recyclable catalyst for imine synthesis by oxidative coupling of alcohols and amines with air as the oxygen source.

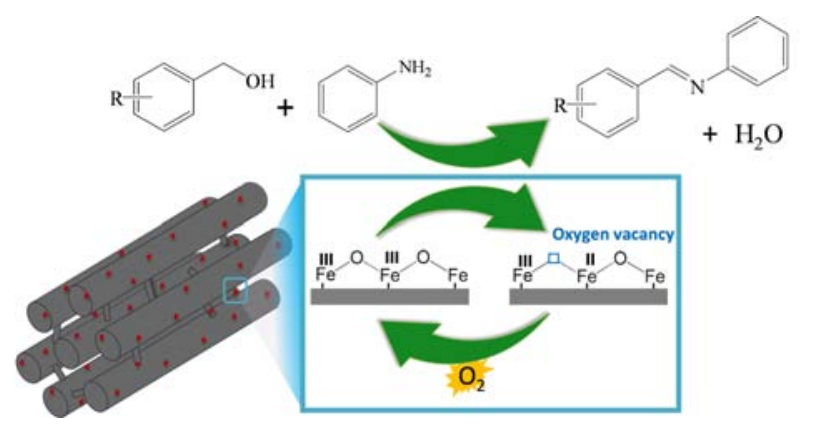


ChemCatChem, 2012, 4, 1997-2004.

[45] Q. Q. Zhuo, J. Gao, M. F. Peng, L. D. Bai, J. J. Deng, Y. J. Xia, Y. Y. Ma, J. Zhong, X. H. Sun, Carbon, 2013, 52, 559-564.

[46] X. L. Mou, B. S. Zhang, Y. Li, L. D. Yao, X. J. Wei, D. S. Su, W. J. Shen, Angew. Chem. Int. Ed., 2012, 51, 2989-2993.

[47] L. Li, A. Q. Wang, B. T. Qiao, J. Lin, Y. Q. Huang, X. D. Wang, T. Zhang,
J. Catal., 2013, 299, 90-100.

[48] E. Zhang, H. W. Tian, S. D. Xu, X. C. Yu, Q. D. Xu, Org. Lett., 2013, 15, 2704-2707.

[49] P. N. Amaniampong, Q. T. Trinh, B. Wang, A. Borgna, Y. Yang, S. H. Mushrif, Angew. Chem. Int. Ed., 2015, 54, 8928-8933.

[50] U. Menon, V. V. Galvita, G. B. Marin, J. Catal., 2011, 283, 1-9.

\title{
介孔炭负载铁基催化剂上醇与胺氧化偶合合成亚胺
}

\author{
耿龙龙，宋金玲，郑涁，吴淑杰，张文祥，贾明君，刘 钢 ${ }^{*}$ \\ 吉林大学化学学院表面与界面化学吉林省重点实验室, 吉林长春130021
}

\begin{abstract}
摘要: 亚胺是一类重要的含氮有机化合物, 广泛应用于生物医药、精细化工和农业生产中. 由于其分子中具有不饱和 C=N 双键, 亚胺化合物可以通过不同化学过程(如氧化还原、加成、偶合等)合成多种衍生物. 工业上合成亚胺普遍采用嶡基化 合物与胺偶合反应获得, 由于该反应需要强酸作为催化剂和脱水剂, 在应用中往往对设备造成不同程度的破坏. 选择氧气 或空气为氧化剂, 通过醇与胺氧化偶合反应合成亚胺, 其副产物只有水, 是一条较为绿色的合成路线. 近期研究表明, 均相 和负载型贵金属催化剂 (如 $\mathrm{Pd}, \mathrm{Pt}$ 和 $\mathrm{Au}$ 等) 在该反应中表现出较好的低温催化性能, 但需要在反应过程中添加大量碱性 助剂. 一些非贵金属氧化物催化剂如 $\mathrm{CeO}_{2}$ 和 $\mathrm{MnO}_{x} / \mathrm{HAP}$ 等在该过程中表现出一定的催化活性, 但其催化效率普遍较低, 往往需要在 $24 \mathrm{~h}$ 甚至更长反应时间实现 $90 \%$ 亚胺收率. 因此仍需开发一些更为高效的非贵金属催化剂用于上述反应.

本文以经过硝酸活化处理的有序多孔炭 (CMK-3) 为载体, 制备了负载型氧化铁催化剂 $\left(\mathrm{FeO}_{x} / \mathrm{HCMK}-3\right)$, 考察了它在苯 甲醇与苯胺氧化偶合合成亚胺反应中的催化性能, 同时结合一系列表征手段研究了催化剂物理化学性质与其催化性能之 间的关系. X 射线衍射和氮吸附脱附结果显示, 负载后的样品仍然保持了介孔炭原有的孔道结构, 没有出现较大的氧化铁 粒子; 透射电镜、高角暗场扫描透射电镜及能量散射谱结果进一步显示, 氧化铁物种相对均匀地分散在载体表面; 程序升 温还原结果显示, 与块体氧化铁相比, $\mathrm{FeO}_{x} / \mathrm{HCMK}-3$ 上的氧化铁物种 $\left(\mathrm{FeO}_{x}\right)$ 更易被还原, 这可能与氧化铁粒子较小有关.

反应结果显示, 在空气氛围中 $\mathrm{FeO}_{x} / \mathrm{HCMK}-3$ 能够高效催化醇与胺的氧化偶合反应, 反应 $6 \mathrm{~h}$ 亚胺收率即达到 $98.8 \%$. 催化剂具有较高的稳定性, 可多次循环使用, 没有检测到铁物种流失. 此外, $\mathrm{FeO}_{x} / \mathrm{HCMK} 3$ 在多种苯甲醇衍生物与苯胺的 氧化偶合反应中都表现出较好的催化性能.

结合表征和反应结果可以推测, 催化剂上的氧物种参与了反应过程, $\mathrm{FeO}_{x} / \mathrm{HCMK}-3$ 催化剂具有较强的活化氧分子的能 力, 反应在该催化剂上可能遵循氧化-还原机理. 该催化剂上醇与胺氧化偶合反应主要经历两个连续的反应过程: 首先苯 甲醇被 $\mathrm{FeO}_{x} / \mathrm{HCMK}-3$ 催化剂上的活泼氧物种氧化生成苯甲醛中间体; 随后, 在反应中生成的醛在催化剂上迅速与胺反应 生成亚胺化合物, 同时催化剂通过与空气中氧分子反应恢复到初始状态, 完成整个催化循环.
\end{abstract}

关键词: 铁基催化剂; 亚胺合成; 氧化偶合; 介孔炭; 分子氧

收稿日期: 2016-05-30. 接受日期: 2016-07-12. 出版日期: 2016-09-05.

*通讯联系人. 电话: (0431)85155390; 传真: (0431)88499140; 电子信箱: lgang@jlu.edu.cn

基金来源：国家自然科学基金(21473073, 21473074); 吉林省教育厅“十三五”科学技术研究项目(2016403).

本文的英文电子版由Elsevier出版社在ScienceDirect上出版(http://www.sciencedirect.com/science/journal/18722067). 